DOI: $10.5937 / \mathrm{MegRev} 2103111 \mathrm{~K}$

Review scientific article

Received 23.12.2020.

Approved 31.12.2020.

\title{
CORPORATE RESPONSIBILITY TOWARDS CHILDREN: THE STATE OF AFFAIRS IN BULGARIA
}

Summary: Child-centred corporate responsibility has significantly evolved in the 21st century. Starting from banning child labour and restricting the advertising of unhealthy food and drinks, through corporate philanthropy, understanding and assessing the overall impact that the business sector can have on children throughout the value chain: in the workplace, marketplace, community and environment. Despite the advanced practice of adopting the "National Corporate Social Responsibility Strategy" and the commitment of the business sector to corporate responsibility in functional, organisational and budgetary terms, the opportunity to integrate children's rights into the strategies and policies of the state, and procedures and practices of the business sector in Bulgaria is missing. The paper gives an overview of how to enhance the National Strategy and expand the priority areas of corporate responsibility for the business sector to systemically improve children's rights in the business principles of responsible companies. As a result, it would allow monitoring the Bulgarian business sector's impact on the full range of children's rights, which is vital for a country facing a gloomy demographic picture and unmet labour market needs.

Keywords: children's rights, Sustainable Development Goals, responsible business, Bulgaria.

Associate Professor, Faculty of Media and Communications, Singidunum University, Belgrade; natasa.krstic@fmk.edu.rs 


\section{Introduction}

The development of corporate responsibility in Bulgaria, as enterprises' responsibility for their impact on society, ${ }^{1}$ began in the last decade of the 20th century ${ }^{2}$. Since then, the number of Bulgarian companies that have started to apply responsible business conduct principles in their work has grown steadily. "This can be explained by the business sector opening to foreign markets, the desire to improve corporate reputation in the eyes of the stakeholders and to reduce the level of non-financial risks" ${ }^{3}$. The latest tendencies in the responsibility demonstrated by Bulgarian businesses show a transition from the traditional ad-hoc charity model to strategic social investments, as most corporate responsibility practices are sustainable in time, which presumes they are much closer to strategy investments than to single acts of philanthropy ${ }^{4}$.

Some of the milestones in the country in connection with corporate responsibility are the National Code for Corporate Governance voluntarily applicable to public companies whose securities are traded on the Bulgarian Stock Exchange ${ }^{5}$, the launch of the first National Corporate Social Responsibility (CSR) Strategy $2009-2013^{6}$ and the introduction of compulsory non-financial reporting ${ }^{7}$. The Republic of Bulgaria is also a signatory of several international commitments,

1 European Commission: "Corporate Social Responsibility". Recommendations to the European Commission by the subgroup on "CORPORATE SOCIAL RESPONSIBILITY" of the Multi-Stakeholder Platform on the Implementation of the Sustainable Development Goals in the EU, https://ec.europa.eu/info/sites/info/files/recommendations-subgroupcorporate-social-responsibility_en.pdf

2 Lyubenova Mariyana Evgenieva (2014): “Corporate Social Responsibility in Bulgaria: Advantages and Challenges", The Małopolska School of Economics in Tarnów Research Papers Collection 25/2, 127-134; Slavova Irena (2015): "Corporate Social Responsibility in Bulgaria: Development, Constraints and Challenges”, Economic Alternatives 1312-7462/2, 113-126.

3 Antonova Diana (2017): "Common Understanding of Corporate Social Responsibility in Bulgaria”, Analele Universității "Eftimie Murgu" Reșița, Fascicola II, Studii Economice 24/2017, 19.

$4 \quad$ Ibid.

5 Nedelchev Miroslav (2017): "Overview of corporate governance in Bulgaria", Entrepreneurship 5/2, 70-76.

$6 \quad$ Kunev Svilen, Kostadinova Irina, Stoycheva Bozhana (2017): “Business Governance and Corporate Social Responsibility in Bulgaria", Analele Universitatii "Eftimie Murgu" Resita, Fascicola II, Studii Economice, 99-115; Arabska Ekaterina (2020): “Communicating Socially Responsible Initiatives: New Incentives to Sustainable Development”, 79-106, in: Anetta Kuna-Marszałek, Agnieszka Kłysik-Uryszek (eds.): CSR and Socially Responsible Investing Strategies in Transitioning and Emerging Economies. Hershey, PA: IGI Global.

7 Bulgarian Chamber of Commerce and Industry: “Председателят на БТПП откри Заключителната конференция по проект Корпоративна социална отговорност за всеки “, https://www.bcci.bg/news/10938 
such as the universal international acts (ILO Conventions on Labor Standards, Universal Declaration of Human Rights, International Covenant on Economic, Social and Cultural Rights), acts of the Council of Europe and of the European Union (Charter of Fundamental Rights of the EU annexed to the Treaty of Lisbon; European Social Charter) and other initiatives (United Nation Global Compact, Standards ISO 26000 and SA 8000) ${ }^{8}$. Consequently, the new version of the CSR Strategy 2019-2023, accompanied with action plans (2019, 2020-2021) was launched, "presenting the Government vision, priority goals and commitment to foster companies' ability to integrate corporate responsibility into their activities". The Strategy's goal is "to improve competitiveness, business sustainability, and support the achievement of Sustainable Development Goals (SDGs) by creating supportive public policies and frameworks that allow the use of different instruments: legal, financial, informational and economic"10. Although the Strategy is linked to the country's socio-economic goals, it does not mention the stimulus of corporate responsibility activities aimed at children. Given the negative demographic trends, poverty rates, and skills mismatches among young people ${ }^{11}$, which substantially impact the future of the country, state incentives for corporate responsibility aimed at children can be a systemic solution.

Children are one of the most vulnerable social groups directly and indirectly influenced by business stakeholders ${ }^{12}$ as members of their employees' families, the local community, future employees, consumers and business leaders. They are part of the communities and environments in which business operates. Through the business products and services, supply chains, manufacturing and marketing methods and distribution practices, and their environmental impact and investments in local communities - businesses leave a footprint on the lives of children, which can be either positive or harmful ${ }^{13}$. At the same time, children are unable to access mechanisms for participation in business decisions and are having difficulties exercising their rights in the event of their violation ${ }^{14}$.

8 Ministry of Labour and Social Policy, Republic of Bulgaria: "Corporate Social Responsibility Strategy 2019-2023”, 2019, 7, https://mlsp.government.bg/index. php?section $=$ CONTENT\&I $=806$

$9 \quad$ Ibid, 2.

$10 \quad$ Ibid, 16.

11 European Commission: “Commission Staff Working Document: Country Report Bulgaria 2020”, 2020/501, https://ec.europa.eu/info/publications/2020-european-semester-countryreports_en

12 Berlan Amanda (2016): "Whose Business is it Anyway: Children and Corporate Social Responsibility in the International Business Agenda", Children \& Society 30/2, 159-168. 9

13 United Nations Children's Fund, Save the Children, Global Compact: “Children's Rights and Business Principles”, 2012, https://www.unicef.org/csr/css/PRINCIPLES_23_02_12_ FINAL_FOR_PRINTER.pdf

14 Gerber Paula, Kyriakakis, Joana, O’Byrne Katie (2013): “General Comment 16 on State Obligations Regarding the Impact of the Business Sector on Children's Rights: What Is Its 
Therefore, companies can consciously or unconsciously contribute to welfare and respect, or breach children's rights. Consequently, the acceptance of socially responsible behavior towards all interest groups, and especially children, enables the corporation to be efficient and effective in business ${ }^{15}$.

The paper aims to determine the state of play regarding corporate responsibility and the fulfillment of child-related SGD to make recommendations for the systemic regulation of children's rights in the Bulgarian business sector. The research subject is the systemic introduction of children's rights in business through the concept of corporate responsibility, as exemplified on the Bulgarian business sector. The methodology includes theoretical research of the available literature, as well as analysis of empirical data on corporate responsibility and sustainable development based on the CSR Strategy of the Government, the most recent survey on CSR within the business sector, and the European Commission report on the implementation of the country's SDGs.

The paper consists of two interrelated parts. The first one provides an overview of the extent of corporate responsibility development in Bulgaria in functional, organizational and budgetary terms, activities of responsible companies aimed at children and the business sector's stance towards realizing its SDGs. The second part contains the proposal of extending the Government's "CSR Strategy" and priority areas of CSR to the business sector through the lens of children's rights, using the UNICEF methodology and guidelines. The conclusion highlights the recommendations for different social stakeholders and outlines the suggestions for future research.

\section{The State of Corporate Responsibility in Bulgaria}

The main driver of corporate responsibility in Bulgaria is unambiguously the business sector ${ }^{16}$. The champions of responsible business in the country are subsidiaries of multinational companies with many employees, mainly in the services sector - information communications technology (ICT), retail chains, banking, and food production who have acknowledged their influence on society ${ }^{17}$. There are also expectations of large employers for more active and concrete intervention in addressing socially significant issues. In the most recent survey within the business sector entitled "The State of CSR in Bulgaria 2018", 43 per cent of compa-

Standing, Meaning and Effect?", Melbourne Journal of International Law 1, 93-128

15 Dokić Dragan (2019): Korporativna društvena odgovornost kao sprega održivog razvoja u prehrambenim kompanijama Republike Srbije “, Megatrend revija 16/3, 45.

16 Bakardjieva Radostina (2019): "Bulgarian Firms as Engine of Corporate Social Responsibility", Economic Studies 28/1, 124-132

17 CSR AdviceBox: "State of CSR in Bulgaria", 2019, 9, https://www.csrab.com/en/products/ state-of-csr-in-bulgaria-2018.html 
nies stated receiving regular inquiries from all groups of stakeholders. Moreover, companies in smaller cities face high expectations from the local community to respond to various initiatives that improve the quality of life of fellow citizens in building infrastructure, supporting educational establishments, disabled persons or disadvantaged groups and environmental initiatives ${ }^{18}$. Two-thirds of the surveyed companies consider their company's engagement in corporate responsibility to be high, reflecting the volume of the budget for responsible activities, which, for half of the companies exceeds 100,000 leva. The companies are also reporting on sustainability, mainly using the UN Global Compact Communication on Progress (COP) report, ISO 26000 and Global Reporting Initiative (GRI) standards ${ }^{19}$. Furthermore, the same research found out that the team's most common size engaged in corporate responsibility activities is between 1-3 members, mainly belonging to the public relations sector ${ }^{20}$. It can be concluded that companies strategically committed to corporate responsibility seek to integrate it into their management systems. However, some of the obstacles in conducting responsible activities that surveyed companies most often cited are:

- In functional terms: lack of executive management commitment, poor implementation of relevant management systems and absence of requirements by the state,

- In organizational terms: unavailability of human resources and expertise,

- In budgetary terms: a shortage of funds for long-term projects.

Moreover, low awareness about the positive impact of corporate responsibility and its good examples are also mentioned ${ }^{21}$.

Today, the power to make a systemic change no longer rests solely with governments and international organizations as the business sector has unparalleled skills, resources and reach. Regardless of their size and industry, companies can play a crucial role in shaping a more sustainable world for children today, and tomorrow. Therefore, it is not surprising that children are the most preferred cause for Bulgarian companies' corporate responsibility projects as any responsible company in Bulgaria has at least one major child-related project. The types of initiatives vary depending on the age of the youngsters ${ }^{22}$ :

0-6 years; projects related to the fight against poverty (support for vulnerable children), public health (building a safe environment for growth) and

$18 \quad$ Ibid, 11.

$19 \quad$ Ibid, 16.

$20 \quad I b i d, 15$.

21 Ibid, 11; Ministry of Labour and Social Policy (2019).

22 United Nations Children's Fund Bulgaria: "The Impact of the Business Sector on Children's Rights in Bulgaria”, 2020, https:/www.unicef.org/bulgaria/media/8896/file/ BGR-Sit-An-Summary.pdf 
to the families of the employees (financial assistance, support for parents through counseling, training, skills-building).

7-14 years; educational projects such as access to education (free textbooks, clothing), early career guidance (career exhibitions, visits to the school) and soft skills building (literacy and computing, problem-solving).

15-24 years; projects mainly focusing on overcoming the transition from education to employment (dual education, internships, mentoring, scholarships, building entrepreneurial skills and start-up financial assistance).

Like the National CSR Strategy, the CSR survey in Bulgaria within the business sector ${ }^{23}$ did not cover the respect and protection of children's rights. Nowadays, corporate responsibilities extend to ensure that children's rights, from the right to education and health to the right to be free from discrimination, are respected at each stage of its value chain. Children should be empowered to have a voice in decisions that affect them in line with the principle of child participation, as outlined in the world's most widely ratified human rights treaty in history - the Convention on the Rights of the Child ${ }^{24}$. Although the UN Guiding Principles on Business and Human Rights ${ }^{25}$ represent a milestone in the business and human rights discussion, recognizing the need for more substantial visibility of children's rights, Save the Children, the UN Global Compact and UNICEF joined forces to develop the Children's Rights and Business Principles (CRBP). The set of ten principles call on businesses to put in place appropriate policies and processes, including a commitment policy and a due diligence process to address potential and actual impacts on children's rights in the following areas ${ }^{26}$ :

- The workplace: companies should provide decent work to young workers, parents, and caregivers (by respecting the rights of young workers and ensuring that the workplace is family-friendly) and ensuring the protection and safety of children in all business activities and facilities.

- The marketplace: companies should ensure that their products and services are safe; they should seek to support children's rights through them and use marketing and advertising that respects and supports children's rights.

- The community and the environment: companies should respect and support children's rights concerning the environment, land acquisition and use, in security arrangements, they should help to protect children affected by

\section{Ibid.}

24 Convention on the Rights of the Child (1989), United Nations General Assembly resolution 44/25.

25 United Nations Human Rights: "Guiding Principles on Business and Human Rights" Office of the High Commissioner, 2011, https://www.ohchr.org/documents/publications/ guidingprinciplesbusinesshr_en.pdf

26 United Nations Children's Fund, Save the Children, Global Compact (2012) 
emergencies and reinforce local community and government efforts to protect and fulfill children's rights.

The CRBP "highlight the diversity of ways in which business affects children, e.g., the impact of overall business operations such as products and services, marketing methods and distribution practices, as well as through relationships with national and local governments, and investments in local communities"27.

\subsection{The Achievement of Sustainable Development Goals}

“The sustainable development paradigm implies linking economic development, environmental protection and social responsibility" ${ }^{28}$. Creating the conditions for future generations to enjoy wellbeing implies that the current generation will leave them an inheritance with total capital that generates growth at no less than what they own. According to the European Commission's recent report, "Bulgaria is making progress towards achieving the United Nations' SDGs"29. The country is well ranked in labour market indicators (SDG 8) as employment rates are on the rise, the share of long term unemployed and young people neither in employment nor in education or training (NEET) is declining and is close to the EU average. Furthermore, in the environmental and climate dimension (SGD 13), Bulgaria is also coping well with renewables' share in gross final energy consumption. Still, it more needs to be done to improve energy efficiency. However, the country is one of the worst performers in the European Union in poverty reduction (SDG 1), which has been exacerbated by adverse developments in reduced inequalities (SDG 10) and by a relatively weak performance in quality education (SDG 4) (ibid). Additionally, due to significant differences in the level of development in different regions, there is a substantial discrepancy in the Regional Sustainable Development Index (RSDI) between Sofia and Lovech ${ }^{30}$.

To link the country's socio-economic priorities with the SDGs, the National Development Programme for the Republic of Bulgaria (Bulgaria 2030) for the period 2017-2021 made a prioritisation of the relevant SDGs, linking them with the medium- and long-term country's development and the 2030 UN Agenda for Sustainable Development "Transforming our World" 31 .

$27 \quad$ Ibid, 3.

28 Ljajic Samir, Stošković Maja, Kostić Aleksandar (2018): "Paradigm of sustainability in the concept of human development”, School of Business 2, 86.

29 European Commission: “Commission Staff Working Document: Country Report Bulgaria 2020”, 2020/501, 5, https://ec.europa.eu/info/publications/2020-european-semester-country-reports_en.

$30 \quad$ Ivanov Ivaylo (2019): "An approach for survey of the sustainable development at regional level: Case of Bulgaria”, International Conference Knowledge-Based Organization 25(1), 249-254.

31 Ministry of Finance, Republic of Bulgaria: "Bulgaria 2030: National Development Program”, 2020, https://www.minfin.bg/en/1394 
When it comes to the business sector, SDGs began to take their place in the agenda of the management committees and boards. It is particularly encouraging that 62 per cent of surveyed companies within the national CSR research explicitly mention SDGs in their strategic policies and documents ${ }^{32}$. As with the obstacles in implementing responsible business, the main challenge lies in raising the executive management awareness, as barely a third of them are sufficiently familiar with SGDs, to be able to integrate them fully into their policies and strategies ${ }^{33}$. Among the adopted 17 Global goals, Bulgarian companies recognise several significant for their work, as presented in Table 1.

Table 1. SGDs for the Bulgarian business sector: major risks, opportunities and areas of investments

\begin{tabular}{|l|l|l|}
\hline Major risks & Major opportunities & Areas of investments \\
\hline SGD 4: Quality education & $\begin{array}{l}\text { SDG 8: Decent work and } \\
\text { economic growth }\end{array}$ & SGD 4: Quality education \\
\hline SGD 13: Climate changes & $\begin{array}{l}\text { SDG 9: Industry, innovation } \\
\text { and infrastructure }\end{array}$ & $\begin{array}{l}\text { SGD 3: Good health and } \\
\text { wellbeing }\end{array}$ \\
\hline
\end{tabular}

Source: Author, based on CSR Advice Box: the State of CSR in Bulgaria, 2019.

\section{Empirical research method}

Although an indispensable part of corporate responsibility is protecting human rights $^{34}$, the business impact on children's rights is often overlooked. Therefore, the empirical research during the months of March-April 2020 analyzed the current level of corporate responsibility development in Bulgaria in functional, organizational and budgetary terms, examining the priority areas and activities towards children and the country's situation regarding the achievement of the SDGs affecting children. The starting point was the recent national academic research on the subject, the first national survey of the business sector - "The State of CSR in Bulgaria"35, the Government's CSR Strategy 2019-2023 and the progress towards SDGs in the framework of the Country Report about Bulgaria, published by the European Commission ${ }^{36}$. Given the findings that children as important stakeholders are neglected in both the "National CSR Strategy" and within the business sector responsibility, the following research question was raised: „How to integrate children's rights into the existing national corporate responsibility strategies and activities of the Bulgarian business sector? "

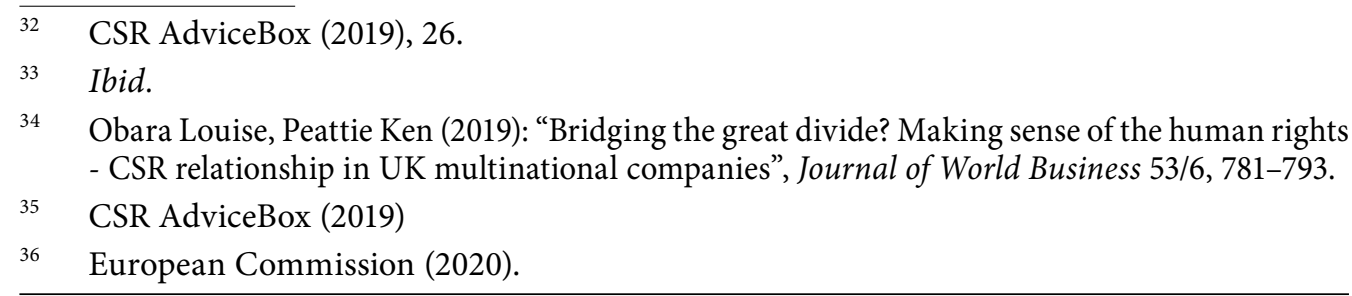


The research question posed in this way entails the advancement of the current National Strategy and priority areas of corporate responsibility in the business sector. In this way, the creators of a sustainable business climate and responsible companies can be shown how they can consider the business sector's impact on the entire spectrum of children's rights. To this end, UNICEF methodologies and guidelines have been applied to raise awareness of the impact of the business sector on children's rights and support businesses to assess their influence on children.

\section{Advancing child rights in the Bulgarian business sector}

Based on the lessons learned from the cabinet research, the empirical research results provide proposals for advancing the "National CSR Strategy" of the Government and for expanding the main findings of the study within the business sector on the state of corporate responsibility, to strategically regulate the impact of the business sector on children's rights. Thereby, the awareness of the business impact on children through the workplace, the marketplace, the community, and the environment, according to the Children's Rights and Business Principles and UNICEF methodologies and guidelines for the business sector will be reinforced.

Consequently, the four strategic objectives set by the Government's CSR Strategy $2019-2023^{37}$ have been broadened by respecting children's rights in the Bulgarian business sector (see Table 2). In that respect, the state would emphasise to the business sector, at which the Strategy is targeted, the importance of respecting children's rights by indirectly regulating them.

Table 2. Bulgarian CSR strategy expanded to include children's rights

\begin{tabular}{|l|l|}
\hline Strategic objective & Children's rights \\
\hline $\begin{array}{l}\text { Sustainable implementation of transparent, } \\
\text { socially responsible management and } \\
\text { business practices. }\end{array}$ & $\begin{array}{l}\text { Respecting and supporting children's rights } \\
\text { in corporate responsibility/sustainability } \\
\text { Indicator: } 10 \% \text { increase in the number of } \\
\text { enterprises reporting corporate responsibility through a review of related policies, } \\
\text { activities for implementing the Strategy. }\end{array}$ \\
$\begin{array}{l}\text { processes and operations } \\
\text { Indicator: } 10 \% \text { increase in the number of } \\
\text { enterprises reporting corporate responsibility } \\
\text { activities, enhanced by reporting on the } \\
\text { impact assessment on children's rights in four } \\
\text { areas }^{39} .\end{array}$ \\
\hline
\end{tabular}

Ministry of Labour and Social Policy (2019), 12.

38 United Nations Children's Fund: “Children’s rights in sustainability reporting”, 2014, https:// www.unicef.org/csr/css/Childrens_Rights_in_Reporting_Second_Edition_HR.pdf

39 United Nations Children's Fund, Danish Institute for Human Rights: “Children's Rights in Impact Assessments”, 2013, https://www.unicef.org/csr/css/Children_s_Rights_in_ Impact_Assessments_Web_161213.pdf 
Promoting a corporate responsibility perspective in case of resource investment and consumption.

Indicator: increase by $5 \%$ in the number of collective agreements concluded in industry, including elements of corporate responsibility for the period of implementation of the Strategy.
Supporting children's rights concerning the environment where future generations will live and grow and assess children's parental workplace impact.

Indicator: when planning and implementing resource-use strategies, ensuring that business operations do not adversely affect children's rights, including damage to the environment or reducing access to natural resources (Principle 7 of Children's Rights in Business). Industrial collective agreements to include family-friendly policies ${ }^{40}$.

Establishing an environment that encourages companies to include national and international practices and requirements for socially responsible behavior and management in their activities.

Indicator: $15 \%$ increase in the number of companies that have purchased ISO $26000 / 2012$ standard on the guidelines for the basic principles of social responsibility, and at least 300 persons who have been trained as corporate responsibility specialists for the period of implementation of the Strategy. Linking corporate responsibility and social entrepreneurship.

Indicator: not less than 150 commercial and/or other partnerships among social enterprises.
Establishing an environment that encourages companies to implement CRBP in their business practice.

Indicator: $70 \%$ of business professionals working in the corporate responsibility functional area should receive UNICEF training on CRBP's.

Source: Author, based on the Ministry of Labor and the Social Policy Republic of Bulgaria: Corporate Social Responsibility Strategy 2019-2023.

Furthermore, Bulgarian companies' priority corporate responsibility fields from the national survey ${ }^{42}$ can be further expanded to include child-rights focused activities (see Table 3).

$40 \quad$ United Nations Children's Fund: "Family-Friendly Policies: Redesigning the Workplace of the Future", 2019, https://www.unicef.org/sites/default/files/2019-07/UNICEF-policybrief-family-friendly-policies-2019.pdf

41 Alam Andaleeb: "Youth entrepreneurship: concepts and evidence" UNICEF Office of Global Insight and Policy, 2020, https://www.unicef.org/globalinsight/reports/youthentrepreneurship-concepts-and-evidence

42 CSR Advice Box (2019), 12. 
Table 3. Priority corporate responsibility fields for companies through the lens of children's rights

\begin{tabular}{|c|c|}
\hline Priority corporate responsibility fields & Children's rights \\
\hline $\begin{array}{l}\text { Active and responsible consumer behaviour } \\
\text { encouragement }\end{array}$ & $\begin{array}{l}\text { Safe products and services for children, } \\
\text { responsible marketing and advertising } \\
\text { practice (Principle } 6 \text { of Children's Rights in } \\
\text { Business) }\end{array}$ \\
\hline $\begin{array}{l}\text { Smart management of resources, energy, } \\
\text { water, emissions, waste and the protection of } \\
\text { the environment }\end{array}$ & $\begin{array}{l}\text { Respecting children's rights concerning the } \\
\text { environment and land usage (Principle } 7 \text { of } \\
\text { Children's Rights in Business) }\end{array}$ \\
\hline Best practices database development & $\begin{array}{l}\text { Best business practices on safeguarding } \\
\text { children's rights }{ }^{43} \text { and commitment to } \\
\text { supporting the human rights of children } \\
\text { (Principle } 1 \text { of Children's Rights in Business) }\end{array}$ \\
\hline $\begin{array}{l}\text { Encouragement of the international corporate } \\
\text { responsibility standards implementation }\end{array}$ & $\begin{array}{l}\text { Promoting children's rights in sustainability } \\
\text { reporting and conducting children's rights } \\
\text { impact assessments }{ }^{44}\end{array}$ \\
\hline $\begin{array}{l}\text { Development of stakeholders' platform } \\
\text { to discuss the most important issues of } \\
\text { sustainability }\end{array}$ & $\begin{array}{l}\text { Business stakeholder platform aiming to } \\
\text { reinforce government and community efforts } \\
\text { to fulfil children's rights (Principle } 10 \text { of } \\
\text { Children's Rights in Business) }\end{array}$ \\
\hline
\end{tabular}

Source: Author, based on CSR Advice Box: the State of CSR in Bulgaria, 2019.

\section{Conclusion}

Based on the conducted analysis, it can be concluded that the Bulgarian business sector does not currently manage in a unified way the impact of its operations on children, despite the existing corporate responsibility reporting systems. The bottlenecks to the implementation of children's rights in functional, organizational and budgetary terms have been identified, as listed below:

- The functional bottleneck for respecting children's rights by Bulgarian businesses: low awareness (and therefore interest) of executive management about how businesses (can) exert a tangible positive and negative impact on children.

- The organizational bottleneck: lack of capacity within the corporate responsibility teams, mostly dealt with by the PR sector, is why they are mainly in branding and gaining positive publicity. The members of the PR/CSR team are passionate but lack the knowledge.

$43 \quad$ United Nations Children's Fund: “Child safeguarding toolkit for business”, 2018, https:// www.unicef.org/csr/files/UNICEF_ChildSafeguardingToolkit_FINAL.PDF

44 UNICEF, Danish Institute for Human Rights (2013); UNICEF (2014). 
- The budgetary bottleneck: volatility, uncertainty, complexity and ambiguity (VUCA) in the business environment, further weakened by the COVID-19 crisis, will become very restrictive for the funding of the corporate responsibility activities.

Given the importance of children for the future sustainability of Bulgaria, as opposed to the mapped corporate responsibility initiatives and priority areas, the necessity to better understand, promote and support the business sector's impact on children and their rights in Bulgaria has been identified. Future steps for the systematic improvement of corporate responsibility towards children with children's rights may include:

1. The National Action Plan (NAP) is adopted on business and human rights to fully implement the UN Guiding Principles on Business and Human Rights in line with EU practice. Ideally, the NAP should be embedded in the "CSR Strategy".

2. Besides the need for the "National CSR Strategy" to recognize and incorporate the impact of the business sector on children's rights, the 2021 Action Plan can envisage initiatives and indicators in children's four impact areas. In this way, systemic support would be provided to companies willing to develop a unified approach to corporate responsibility for children.

3. Raising awareness of the CRBP in the Bulgarian business sector through tailored workshops and supporting the business sector to develop teams that would address their impact on children. Such initiatives can be based on the UNICEF's global reference and online tools, guidelines and methodologies to support companies in conducting a business impact assessment on children's rights and integrating children's rights into corporate policies, codes of conduct and non-financial or sustainability reports.

4. Promote and introduce CRBP at the top management level so that the management acknowledges that children's rights are crucially important for the company's sustainability and the achievement of the country's SDGs.

5. The compulsory non-financial reporting project of the Bulgarian Chamber of Commerce and Industry should be expanded with CRBP, based on the UNICEF's guidelines for the inclusion of children's rights into the Global Reporting Initiative.

Finally, the recommendation for future research would be to conduct quantitative research among systemic, responsible, large/medium companies in Bulgaria on awareness and application of the CRBP in their business practice, policies and procedures. 


\section{Acknowledgements}

The research was part of the project "The Impact of the Business Sector on Children Rights in Bulgaria” for the United Nations Children's Fund Bulgaria during March-April 2020.

\section{Literature:}

- Alam Andaleeb: "Youth entrepreneurship: concepts and evidence" UNICEF Office of Global Insight and Policy, 2020, https://www.unicef.org/globalinsight/reports/youth-entrepreneurship-concepts-and-evidence

- Antonova Diana (2017): "Common Understanding of Corporate Social Responsibility in Bulgaria”, Analele Universității „Eftimie Murgu” Reșița, Fascicola II, Studii Economice 24/2017, 7-22

- Arabska Ekaterina (2020): "Communicating Socially Responsible Initiatives: New Incentives to Sustainable Development”, 79-106, in: Anetta KunaMarszałek, Agnieszka Kłysik-Uryszek (eds.): CSR and Socially Responsible Investing Strategies in Transitioning and Emerging Economies. Hershey, PA: IGI Global. doi: 10.4018/978-1-7998-2193-9.ch005

- Bakardjieva Radostina (2019): "Bulgarian Firms as Engine of Corporate Social Responsibility”, Economic Studies 28/1, 124-132

- Berlan Amanda (2016): "Whose Business is it Anyway: Children and Corporate Social Responsibility in the International Business Agenda", Children \& Society 30/2, 159-168. https://doi.org/10.1111/chso.12149

- Bulgarian Chamber of Commerce and Industry: "Председателят на БТПП откри Заключителната конференция по проект Корпоративна социална отговорност за всеки “, https://www.bcci.bg/news/10938 (17.4.2020).

- Bulgarian Stock Exchange: "Index of the companies having good corporate governance (CGIX)", https://www.bse-sofia.bg/en/corporate-governance (1.7.2020).

- Convention on the Rights of the Child (1989), United Nations General Assembly resolution 44/25

- CSR Advice Box: "State of CSR in Bulgaria”, 2019, https://www.csrab.com/ en/products/state-of-csr-in-bulgaria-2018.html (17/7.2020).

- Dokić Dragan (2019): Korporativna društvena odgovornost kao sprega održivog razvoja u prehrambenim kompanijama Republike Srbije “, Megatrend revija 16/3, 31-48. doi: 10.5937/MegRev1903031D

- European Commission: "Corporate Social Responsibility, https://ec.europa. eu/info/sites/info/files/recommendations-subgroup-corporate-social-responsibility_en.pdf (18.4.2020.) 
- European Commission: "Commission Staff Working Document: Country Report Bulgaria 2020", 2020/501, https://ec.europa.eu/info/ publications/2020-european-semester-country-reports_en (18.4.2020).

- Gerber Paula, Kyriakakis, Joana, O’Byrne Katie (2013): “General Comment 16 on State Obligations Regarding the Impact of the Business Sector on Children's Rights: What Is Its Standing, Meaning and Effect?", Melbourne Journal of International Law 1, 93-128

- Ivanov Ivaylo (2019): “An approach for survey of the sustainable development at regional level: Case of Bulgaria", International Conference KnowledgeBased Organization 25(1), 249-254. doi: 10.2478/kbo-2019-0041

- Kunev Svilen, Kostadinova Irina, Stoycheva Bozhana (2017): "Business Governance and Corporate Social Responsibility in Bulgaria”, Analele Universitatii "Eftimie Murgu" Resita, Fascicola II, Studii Economice, 99-115

- Ljajic Samir, Stošković Maja, Kostić Aleksandar (2018): "Paradigm of sustainability in the concept of human development", School of Business 2, 83-97. https://doi.org/10.5937/skolbiz2-19415

- Lyubenova Mariyana Evgenieva (2014): “Corporate Social Responsibility in Bulgaria: Advantages and Challenges", The Małopolska School of Economics in Tarnów Research Papers Collection 25/2, 127-134.

- Ministry of Finance, Republic of Bulgaria: "Bulgaria 2030: National Development Program”, 2020, https://www.minfin.bg/en/1394 (2.5.2020).

- Ministry of Labor and Social Policy, Republic of Bulgaria: "Corporate Social Responsibility Strategy 2019-2023”, 2019, https://mlsp.government.bg/index. php?section=CONTENT\&I=806 (7.5.2020).

- Nedelchev Miroslav (2017): "Overview of corporate governance in Bulgaria”, Entrepreneurship 5/2, 70-76.

- $\quad$ Obara Louise, Peattie Ken (2019): "Bridging the great divide? Making sense of the human rights - CSR relationship in UK multinational companies", Journal of World Business 53/6, 781-793. https://doi.org/10.1016/j.jwb.2017.10.002

- Slavova Irena (2015): "Corporate Social Responsibility in Bulgaria: Development, Constraints and Challenges", Economic Alternatives 1312-7462/2, 113-126.

- United Nations Children's Fund: “Family-Friendly Policies: Redesigning the Workplace of the Future", 2019, https://www.unicef.org/sites/default/files/2019-07/UNICEF-policy-brief-family-friendly-policies-2019.pdf (1.5.2020).

- United Nations Children's Fund: "Child safeguarding toolkit for business", 2018, https://www.unicef.org/csr/files/UNICEF_ChildSafeguardingToolkit_ FINAL.PDF (7.5.2020).

- United Nations Children's Fund: “Children's rights in sustainability reporting”, 2014, https://www.unicef.org/csr/css/Childrens_Rights_in_Reporting_Second_Edition_HR.pdf (7.5.2020). 
- United Nations Children's Fund Bulgaria: “The Impact of the Business Sector on Children's Rights in Bulgaria”, 2020, https://www.unicef.org/bulgaria/media/8896/file/BGR-Sit-An-Summary.pdf.pdf (22.12.2020).

- United Nations Children's Fund Bulgaria: "Situation Analysis of Children and Women in Bulgaria", 2018, https://www.unicef.org/bulgaria/en/reports/ situation-analysis-children-and-women-bulgaria (27.4.2020).

- United Nations Children's Fund, Danish Institute for Human Rights: "Children's Rights in Impact Assessments", 2013, https://www.unicef.org/ csr/css/Children_s_Rights_in_Impact_Assessments_Web_161213.pdf (13.5.2020).

- United Nations Children's Fund, Save the Children, Global Compact: "Children's Rights and Business Principles", 2012, https://www.unicef.org/ csr/css/PRINCIPLES_23_02_12_FINAL_FOR_PRINTER.pdf (28.4.2020).

- United Nations Human Rights: "Guiding Principles on Business and Human Rights" Office of the High Commissioner, 2011, https:/www.ohchr.org/ documents/publications/guidingprinciplesbusinesshr_en.pdf (7.8.2020).

- United Nations Human Rights: "State National Action Plans on Business and Human Rights", Office of the High Commissioner, https://www.ohchr. org/EN/Issues/Business/Pages/NationalActionPlans.aspx (3.5.2020). 
DOI: 10.5937/MegRev2103111K Pregledni naučni članak Primljen 23.12.2020. Odobren 31.12.2020.

\section{DRUŠTVENO ODGOVORNO POSLOVANJE USMERENO KA DECI U BUGARSKOJ: STANJE STVARI}

Sažetak: Korporativna odgovornost usmerena prema deci značajno se razvila u 21. veku; od zabrane dečijeg rada i ograničavanja oglašavanja nezdrave hrane i pića, kroz korporativnu filantropiju, do razumevanja i procene ukupnog uticaja koji poslovni sektor može da ima na decu u čitavom lancu vrednosti: na radnom mestu, tržištu, zajednici $i$ životnoj sredini. Uprkos naprednoj praksi usvajanja Nacionalne strategije i strateške posvećenosti poslovnog sektora ka društveno odgovornom poslovanju u funkcionalnom, organizacionom $i$ budžetskom pogledu, propuštena je prilika da se prava dece integrišu $u$ državne strategije i politike, kao i procedure i prakse poslovnog sektora u Bugarskoj. Članak daje prikaz kako je moguće unaprediti Nacionalnu strategiju i proširiti prioritetne oblasti društveno odgovornog poslovanja za poslovni sektor, s ciljem sistemskog unapredenja prava dece u principe poslovanja odgovornih preduzeća. Kao rezultat, omogućilo bi se sistemsko praćenje uticaja bugarskog poslovnog sektora na ceo spektar prava dece, što je od značaja za zemlju koja se suočava sa negativnom demografskom slikom i nezadovoljenim potrebama trzišta rada.

Ključne reči: prava dece, ciljevi održivog razvoja, odgovorno poslovanje, Bugarska. 